\title{
Characterization of Streptomyces piniterrae sp. nov. and Identification of the Putative Gene Cluster Encoding the Biosynthesis of Heliquinomycins
}

\author{
Xiaoxin Zhuang ${ }^{1,+}$, Zhiyan Wang ${ }^{2,+}$, Chenghui Peng ${ }^{1}$, Can Su ${ }^{2}$, Congting Gao ${ }^{1}$, \\ Yongjiang Wang ${ }^{2}$, Shengxiong Huang ${ }^{2, * \mathbb{D}}$ and Chongxi Liu ${ }^{1, * \mathbb{D}}$ \\ 1 Key Laboratory of Agricultural Microbiology of Heilongjiang Province, Northeast Agricultural University, \\ Harbin 150030, China; zxx221661@163.com (X.Z.); ppoapeng@163.com (C.P.); g2456692645@163.com (C.G.) \\ 2 State Key Laboratory of Phytochemistry and Plant Resources in West China, Kunming Institute of Botany, \\ Chinese Academy of Sciences, Kunming 650201, China; zhiyan_w@163.com (Z.W.); \\ sucan126@126.com (C.S.); wangyongjiang@mail.kib.ac.cn (Y.W.) \\ * Correspondence: sxhuang@mail.kib.ac.cn (S.H.); xizi-ok@163.com (C.L.) \\ $\dagger$ These authors contributed equally to this work.
}

Received: 20 March 2020; Accepted: 30 March 2020; Published: 31 March 2020

\begin{abstract}
A novel actinomycete producing heliquinomycin and $9^{\prime}$-methoxy-heliquinomycin, designated strain jys $28^{\mathrm{T}}$, was isolated from rhizosphere soil of Pinus yunnanensis and characterized using a polyphasic approach. The strain had morphological characteristics and chemotaxonomic properties identical to those of members of the genus Streptomyces. It formed spiral chains of spores with spiny surfaces. The menaquinones detected were MK-9 $\left(\mathrm{H}_{6}\right), \mathrm{MK}-9\left(\mathrm{H}_{8}\right)$ and MK-9 $\left(\mathrm{H}_{4}\right)$. The major fatty acids were iso- $\mathrm{C}_{16: 0}, \mathrm{C}_{15: 0}, \mathrm{C}_{16: 1} \omega 7 \mathrm{cand}$ anteiso- $\mathrm{C}_{15: 0}$. The phospholipids were diphosphatidylglycerol, phosphatidylmethylethanolamine, phosphatidylethanolamine and phosphatidylinositol mannoside. The DNA G + C content of the draft genome sequence, consisting of $8.5 \mathrm{Mbp}$, was $70.6 \%$. Analysis of the 16S rRNA gene sequence showed that strain jys $28^{\mathrm{T}}$ belongs to the genus Streptomyces with the highest sequence similarities to Streptomyces chattanoogensis NBRC $13058^{\mathrm{T}}(99.2 \%)$ and Streptomyces lydicus DSM $40002^{\mathrm{T}}(99.2 \%)$ and phylogenetically clustered with them. Multilocus sequence analysis based on five other house-keeping genes $(a t p \mathrm{D}, g y r \mathrm{~B}, r p o \mathrm{~B}, r e c \mathrm{~A}$ and $\operatorname{tr} p \mathrm{~B})$ and the low level of DNA-DNA relatedness and phenotypic differences allowed the novel isolate to be differentiated from its most closely related strains. Therefore, the strain is concluded to represent a novel species of the genus Streptomyces, for which the name Streptomyces piniterrae sp. nov. is proposed. Furthermore, the putative biosynthetic gene cluster of heliquinomycins was identified and the biosynthetic pathway was discussed. The type strain is jys $28^{\mathrm{T}}\left(=\right.$ CCTCC AA $\left.2018051^{\mathrm{T}}=\mathrm{DSM} 109823^{\mathrm{T}}\right)$.
\end{abstract}

Keywords: Streptomycespiniterrae sp. nov.; heliquinomycins; Pinus yunnanensis; genome analysis; biosynthetic gene cluster

\section{Introduction}

Actinobacteria has been the most fruitful source of microorganisms for all types of bioactive metabolites, including antibiotics, immunosuppressive agents, antitumor agents, and enzymes [1]. Actinobacteria belonging to the genus Streptomyces, in particular, are excellent producers. Multiple structural types of antibiotics, including amino glycosides, chloramphenicol, tetracyclines, macrolides and $\beta$-lactams, have been isolated from cultures of this genus [2]. During our continuous efforts to discover new or bioactive natural products from actinobacteria, we have reported the chemical studies of Streptomyces piniterrae jys $28^{\mathrm{T}}$ isolated from rhizosphere soil of Pinus yunnanensis, and identified heliquinomycin and its new analogue, 9'-methoxy-heliquinomycin [3]. 
Since the initial isolation and discovery of rubromycins in 1953 from Streptomyces collinus, more abundant compounds of rubromycin family, including purpuromycin, griseorhodins and heliquinomycins, have been identified by the end of the 20th century [4-7]. Multitude of them exhibit different activities on microbial inhibition, cytotoxicity, DNA helicases inhibition, telomerase inhibition or HIV reverse transcriptase inhibition, which implied the possibility of rubromycin family as potential medicinal chemistry precursors [8-10]. Besides the diverse bioactivity, the complex intriguing spiroketal core of rubromycins has attracted the attention of several research groups for chemical synthesis and biosynthesis studies. Several total synthesis strategies have been successfully established for rubromycin compounds, whereas, the biosynthetic conversions of rubromycins still exist a lot uncertainties [11-15]. With the clear recognition of biosynthetic gene clusters of rubromycins, further studies of the individual enzymes are required to determine the exact biosynthetic pathway.

In this study, we investigated the taxonomic status of strain jys $28^{\mathrm{T}}$ using a polyphasic approach and surveyed the biosynthetic gene cluster of heliquinomycins in the genome.

\section{Materials and Methods}

\subsection{Strains}

Strain jys $28^{\mathrm{T}}$ was isolated from rhizosphere soil of Pinus yunnanensis collected from Yuxi, Yunnan Province, southwest China $\left(24^{\circ} 21^{\prime} \mathrm{N}, 102^{\circ} 32^{\prime} \mathrm{E}\right)$. The rhizosphere soil sample was air-dried for 14 days at room temperature, suspended in sterile distilled water followed by a standard serial dilution technique and spread on dulcitol-proline agar (DPA) [16] supplemented with cycloheximide $\left(50 \mathrm{mg} \mathrm{L}^{-1}\right)$ and nalidixic acid $\left(20 \mathrm{mg} \mathrm{L}^{-1}\right)$. After 21 days of aerobic incubation at $28^{\circ} \mathrm{C}$, colonies were transferred and purified on oatmeal agar [International Streptomyces Project (ISP) medium 3] [17] and maintained as glycerol suspensions $(20 \%, v / v)$ at $-80^{\circ} \mathrm{C}$. The reference strains, Streptomyces chattanoogensis NBRC $13058^{\mathrm{T}}$ and Streptomyces lydicus DSM $40002^{\mathrm{T}}$, were purchased from the Deutsche Sammlung von Mikroorganismen und Zellkulturen (DSMZ) for comparative analysis.

\subsection{Phenotypic Characterization}

Spore morphology was observed using scanning electron microscopy (Hitachi SU8010, Hitachi Co., Tokyo, Japan) after cultivation on ISP 3 medium at $28^{\circ} \mathrm{C}$ for 4 weeks. Cultural characteristics were determined after 2 weeks at $28^{\circ} \mathrm{C}$ using ISP media 1-7 [17], modified Bennett's agar (MBA) [18], Nutrient agar (NA) [19], and Czapek's agar (CA) [19]. Growth at different temperatures $(4,10,15,18$, $25,28,35,37,40$ and $45^{\circ} \mathrm{C}$ ) was determined on ISP 3 agar after incubation for 2 weeks. Tolerance of $\mathrm{pH}$ range ( $\mathrm{pH} 4-11$, at intervals of $1 \mathrm{pH}$ units), using buffer system described by Zhao et al. [20] and $\mathrm{NaCl}$ tolerance $(0-13 \%$, with an interval of $1 \%, w / v)$ for growth were determined after 2 weeks growth in ISP 2 broth in shake flasks $(250 \mathrm{rpm})$ at $28^{\circ} \mathrm{C}$. The utilization of sole carbon and nitrogen sources at a final concentration of $0.5 \%(w / v)$ was tested using ISP 9 agar as the basal medium following the methods of Gordon et al. [21]. Other physiological and biochemical characteristics were conducted based on a previous report [22].

\subsection{Chemotaxonomic Characterization}

Biomass for chemical studies was prepared by growing strain jys $28^{\mathrm{T}}$ in ISP 2 broth in shake flasks at $28^{\circ} \mathrm{C}$ for 5 days. The isomers of diaminopimelic acid (DAP) in the cell wall were derivatized according to McKerrow et al. [23], and analyzed by a HPLC method using an Agilent TC-C18 Column (250 $\times$ $4.6 \mathrm{~mm}$ i.d. $5 \mu \mathrm{m}$ ) [22]. The whole-cell sugars were analyzed according to the procedures developed by Lechevalier and Lechevalier [24]. Phospholipids in cells were examined by two-dimensional TLC (thin-layer chromatography, Qingdao Marine Chemical Inc., Qingdao, China) and identified using the method of Minnikin et al. [25]. Menaquinones were extracted from freeze-dried biomass and purified according to Collins [26] and analyzed by a HPLC-UV method as described previously [22]. Fatty acids were prepared and analyzed by GC-MS using the method of Zhuang et al. [27]. 


\subsection{Phylogenetic Analysis}

The 16S rRNA sequence was determined as described by Wang et al. [28], and similarities between strain jys $28^{\mathrm{T}}$ and other type strains of valid species were calculated based on pairwise alignment using the EzTaxon-e server (https://www.ezbiocloud.net/) [29]. Phylogenetic trees were constructed using the neighbour-joining [30] and the maximum likelihood [31] algorithms with Kimura's two-parameter model [32] via molecular evolutionary genetics analysis (MEGA) software version 7.0 [33]. Phylogenetic relationships of strain jys $28^{\mathrm{T}}$ were also confirmed using sequences for five individual housekeeping genes $(r e c \mathrm{~A}, g y r \mathrm{~B}, a t p \mathrm{D}, r p o \mathrm{~B}$ and $\operatorname{tr} p \mathrm{~B})(2481 \mathrm{bp})$. The sequences of $\mathrm{jys} 28^{\mathrm{T}}$ were obtained from the whole genome. The sequences of each locus were aligned using MEGA 7.0 software and trimmed manually at the same position before being used for further analysis. Phylogenetic analysis was performed as described above.

\subsection{Genome Analysis}

Genomic DNA was extracted according to the lysozyme-sodium dodecyl sulfate-phenol/chloroform method [34]. Whole-genome sequencing was performed on HiSeq 2500 Sequencing System (Illumina, San Diego, CA, USA) according to the User Guide and assembling on MiSeq plateform [35]. Genome mining analysis was performed with antiSMASH (version 4.0, Blin K, Oxford, UK) [36]. The digital DNA-DNA hybridization ( $\mathrm{dDDH}$ ) and average nucleotide identity (ANI) values were determined between the draft genome sequences of strain jys $28^{\mathrm{T}}$ and S. chattanoogensis NBRC $13058^{\mathrm{T}}$ (LGKG01000001) and S. lydicus DSM 40002 ${ }^{\mathrm{T}}$ (CP007699) online at http://ggdc.dsmz.de using the Genome-to-Genome Distance Calculation (GGDC 2.0) [37] and the ChunLab's online ANI Calculator (www.ezbiocloud.net/tools/ani) [38], respectively.

\section{Results and Discussion}

\subsection{Polyphasic Taxonomic Characterization of Strain jys $28^{T}$}

Identification using the EzTaxon-e server revealed that strain jys $28^{\mathrm{T}}$ belonged to the genus Streptomyces with the highest $16 \mathrm{~S}$ rRNA gene sequence similarities to S. chattanoogensis NBRC $13058^{\mathrm{T}}$ $(99.2 \%)$ and S. lydicus DSM $40002^{\mathrm{T}}(99.2 \%)$. 16S rRNA gene sequence similarities between strain jys $28^{\mathrm{T}}$ and other species of the genus Streptomyces were lower than $99.0 \%$. Phylogenetic analysis based on the 16S rRNA gene sequences indicated that the isolate clustered with the above-mentioned strains in the neighbour-joining tree (Figure 1). The tree topology in this region was also supported by the maximum-likelihood (Figure $\mathrm{S} 1$ ). To further clarify the affiliation of strain jys $28^{\mathrm{T}}$ to its closely related strains, partial sequences of housekeeping genes including $\operatorname{atp} \mathrm{D}, g y r \mathrm{~B}, r e c \mathrm{~A}, r p o \mathrm{~B}$ and $\operatorname{tr} p \mathrm{~B}$ were obtained, the accession numbers for the Streptomyces sequences used are given in Table S1 and phylogenetic trees based on the neighbour-joining and maximum-likelihood algorithms were reconstructed from the concatenated sequence alignment (2481 bp) of the five housekeeping genes. The multilocus sequence analysis (MLSA) trees exhibited the close association between strain jys $28^{\mathrm{T}}$ and S. lydicus DSM $40002^{\mathrm{T}}$ (Figure 2 and Figure S2). Based on the phylogenetic trees and 16S rRNA gene similarities, the isolate was mostly related to S. chattanoogensis NBRC $13058^{\mathrm{T}}$ and S. lydicus DSM $40002^{\mathrm{T}}$. dDDH indicated that DNA-DNA relatedness between strain jys $28^{\mathrm{T}}$ and $S$. chattanoogensis NBRC $13058^{\mathrm{T}}$ and S. lydicus DSM $40002^{\mathrm{T}}$ were $27.6-32.5 \%$ and $27.5-32.4 \%$, respectively, which are much lower than the cut-off point of $70 \%$ recommended for the assignment of bacteria strains to the same genomic species [39]. ANI values between $\mathrm{jys} 28^{\mathrm{T}}$ and the two type strains were $84.9 \%$ and $85.0 \%$, respectively, whose values are also below the recommended threshold for species delineation (95-96\%) [40]. In addition, The MLSA distances between the isolate and the two type strains were 0.057 and 0.044 , respectively (Table S2), which was well above the species level threshold of 0.007 considered to be the threshold for species determination [41]. 


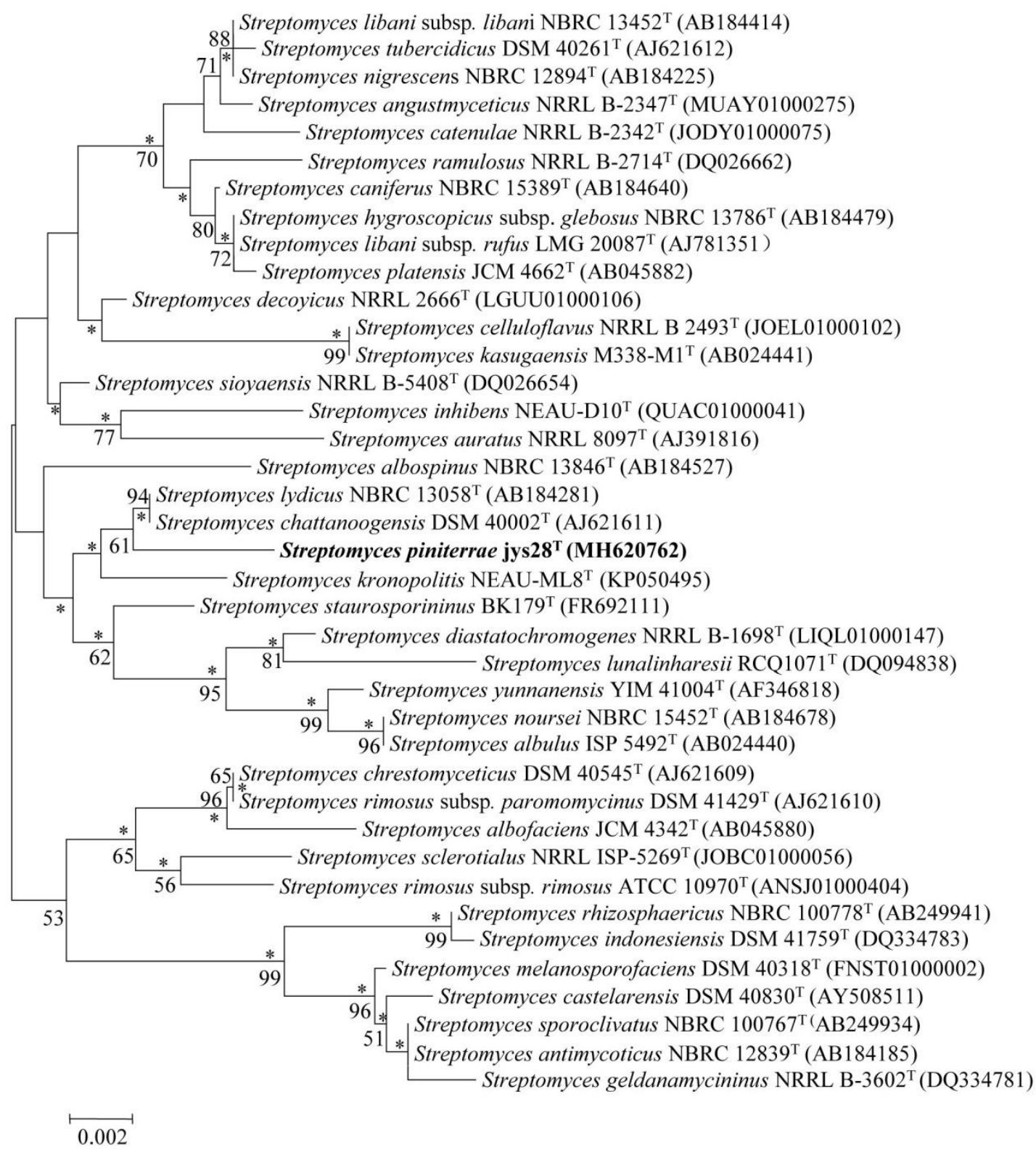

Figure 1. Neighbour-joining tree showing the phylogenetic position of strain jys $28^{\mathrm{T}}$ and related taxa based on 16S rRNA gene sequences. Asterisks indicate branches that were also found using the maximum-likelihood method. Numbers at branch points indicate bootstrap percentages (based on 1000 replicates); only values $>50 \%$ are indicated. Bar, 0.002 substitutions per nucleotide position.

Morphological observation of a 4-week-old culture of strain jys $28^{\mathrm{T}}$ growth on ISP 3 medium revealed that it has the typical characteristics of the members of the genus Streptomyces [42]. Aerial and substrate mycelia were well developed without fragmentation. Spiral spore chains were observed, and spores $(0.5-0.6 \times 0.8-0.9 \mu \mathrm{m})$ were spiny and non-motile (Figure 3). Good growth was observed on all tested media. The colours of aerial mycelium varied from pure white to dark gray, and those of the substrate mycelium varied from brilliant yellow to dark purplish red. Diffusible pigments were observed on ISP 2, ISP 3, ISP 5, ISP 6, ISP 7, NA and CA. The significant colour variations of aerial and substrate mycelium and production of diffusible pigments on different media are listed in Table S4, which shows some morphological differences between the isolate and its closely related strains. Strain jys $28^{\mathrm{T}}$ could grow at $40{ }^{\circ} \mathrm{C}$, while its closely related strains could not. The utilization of L-arabinose and L-threonine, and hydrolysis of aesculin could also distinguish it from its closely related strains. Most notably, strain jys $28^{\mathrm{T}}$ could be distinguished readily from its closely related strains on the basis 
of $\mathrm{NaCl}$ tolerance. Other physiological and biochemical characteristics of strain jys $28^{\mathrm{T}}$ compared with its closely related strains are listed in Table 1.

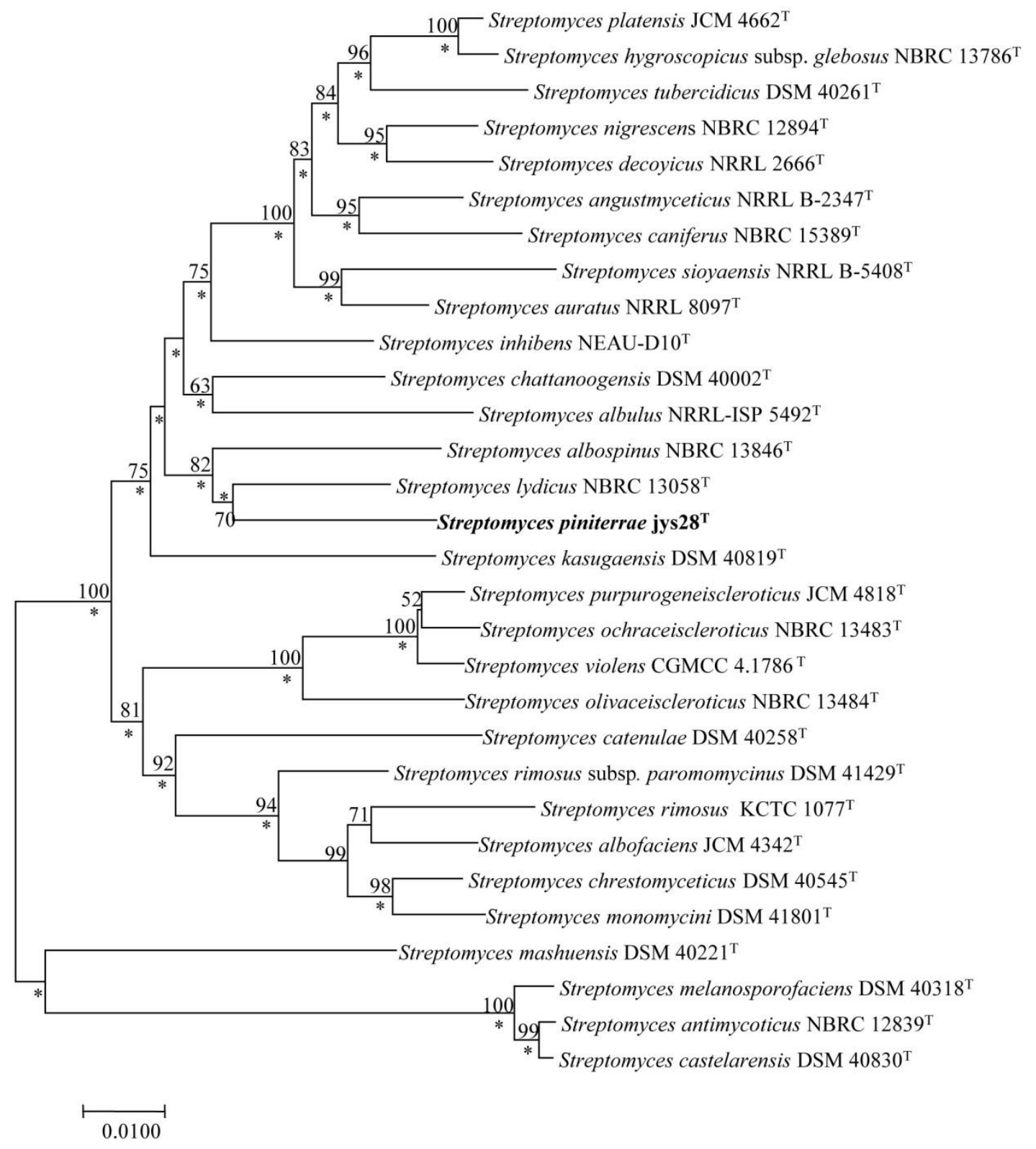

Figure 2. Neighbour-joining tree based on MLSA analysis of the concatenated partial sequences (2481 $\mathrm{bp})$ from five housekeeping genes $(\operatorname{atp} \mathrm{D}, g y r \mathrm{~B}, r e c \mathrm{~A}, r p o \mathrm{~B}$ and $\operatorname{tr} p \mathrm{~B})$ of strain jys $28^{\mathrm{T}}$ and related taxa. Only bootstrap values above $50 \%$ (percentages of 1000 replications) are indicated. Asterisks indicate branches also recovered in the maximum-likelihood tree. Bar, 0.01 nucleotide substitutions per site. 


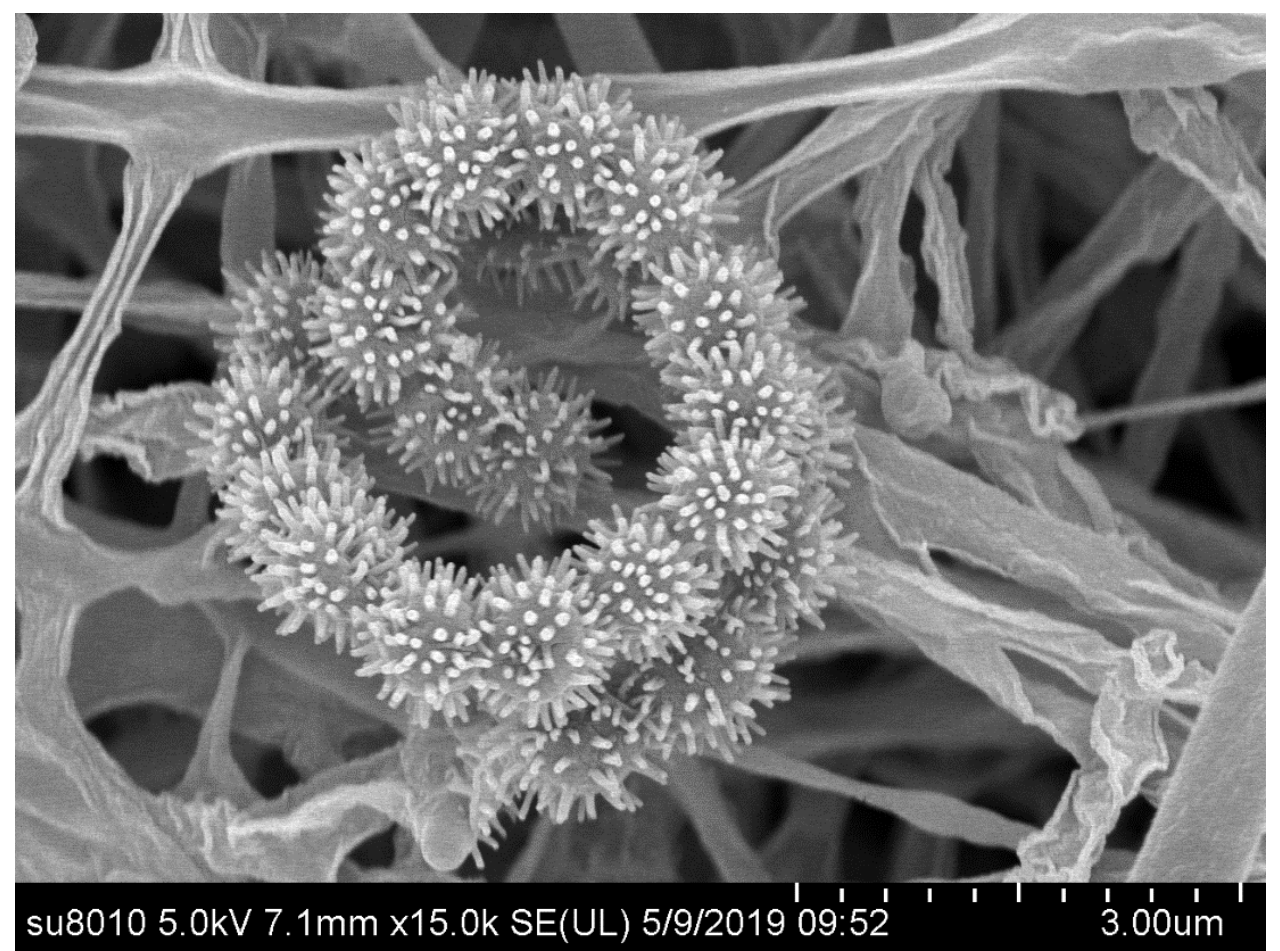

Figure 3. Scanning electron micrograph of strain jys $28^{\mathrm{T}}$ grown on ISP 3 agar for 4 weeks at $28^{\circ} \mathrm{C}$.

Table 1. Differential characteristics of strain jys $28^{\mathrm{T}}$ and its closely related strains. Strains: 1 , jys $28^{\mathrm{T}} ; 2$, S. chattanoogensis DSM $40002^{\mathrm{T}} ; 3$, S. lydicus NBRC $13058^{\mathrm{T}}$. All data are from this study except as labeled.

${ }^{\text {a }}$ Data from Kim et al. [43]. +, positive; -, negative.

\begin{tabular}{cccc}
\hline Characteristic & $\mathbf{1}$ & $\mathbf{2}$ & $\mathbf{3}$ \\
\hline Spore surface & Spiny & Spiny & Smooth \\
Hydrolysis of aesculin & - & + & + \\
Production of $\mathrm{H}_{2} \mathrm{~S}$ & - & + & - \\
Carbon source utilization & & & + \\
L-arabinose & - & + & + \\
Lactose & + & - & + \\
L-rhamnose & + & - & + \\
D-ribose & + & - & + \\
D-xylose & - & & + \\
L-aspartic acid & & - & + \\
L-threonine & + & + & + \\
L-tryptophan & - & - & $5-9$ \\
pH range for growth & - & -9 & - \\
Growth at $40{ }^{\circ} \mathrm{C}$ & + & 2 & 2 \\
Tolerance of $\mathrm{NaCl}(\%, w / v)$ & 11 & & + \\
\hline
\end{tabular}

Chemotaxonomic analysis revealed that strain $\mathrm{jys} 28^{\mathrm{T}}$ exhibited characteristics which are typical of members of the genus Streptomyces [42]. It contained LL-diaminopimelic acid as the cell-wall diamino acid and whole-cell sugars included glucose and xylose. The phospholipid profile was consisted of diphosphatidylglycerol, phosphatidylmethylethanolamine, phosphatidylethanolamine and phosphatidylinositol mannoside (phospholipid type II) [44] (Figure S3). The menaquinones detected were MK-9 $\left(\mathrm{H}_{6}\right)(53.1 \%)$, MK-9 $\left(\mathrm{H}_{8}\right)(23.9 \%)$ and MK-9 $\left(\mathrm{H}_{4}\right)(23.0 \%)$. The major cellular fatty acids (> 10\%) were iso- $\mathrm{C}_{16: 0}(25.3 \%), \mathrm{C}_{15: 0}(15.8 \%), \mathrm{C}_{16: 1} \omega 7 \mathrm{c}(11.9 \%)$ and anteiso- $\mathrm{C}_{15: 0}(11.7 \%)$ (Table 2). The fatty acid profile of strain jys $28^{\mathrm{T}}$ was evidently different from those of $S$. chattanoogensis NBRC $13058^{\mathrm{T}}$ and S. lydicus DSM $40002^{\mathrm{T}}$, such as the presence of saturated fatty acids $\left(\mathrm{C}_{16: 0}\right.$ and $\left.\mathrm{C}_{18: 0}\right)$ as the 
major fatty acids and absence of most branched fatty acids (anteiso- $C_{15: 0}$, anteiso- $C_{17: 0}$ and iso- $C_{14: 0}$ ) in S. chattanoogensis NBRC $13058^{\mathrm{T}}$, the presence of $C_{14: 0}$ and absence of $C_{17: 0}$ and iso- $C_{14: 0}$ in $S$. lydicus DSM $40002^{\mathrm{T}}$.

Table 2. The cellular fatty acid compositions of strain jys $28^{\mathrm{T}}$ and its closely related strains. Strains: 1 , jys $28^{\mathrm{T}} ; 2$, Streptomyces chattanoogensis NBRC $13058^{\mathrm{T}} ; 3$, Streptomyces lydicus DSM $40002^{\mathrm{T}}$. Values are percentages of total fatty acids. Fatty acids representing $<1 \%$ in all strains were omitted. All data are from this study, and all strains were cultivated in ISP 2 broth for 5 days under. the same conditions. -, not detected.

\begin{tabular}{cccc}
\hline Fatty Acid & $\mathbf{1}$ & $\mathbf{2}$ & $\mathbf{3}$ \\
\hline Saturated fatty acids & & & \\
C14:0 & - & - & 14.3 \\
C15:0 & 15.8 & - & 18.2 \\
C16:0 & 5.8 & 30.0 & 28.4 \\
$\mathrm{C}_{17: 0}$ & 6.9 & 1.7 & - \\
$\mathrm{C}_{18: 0}$ & 1.0 & 41.4 & 1.8 \\
$\mathrm{C}_{16: 1} \omega 7 \mathrm{c}$ & & & \\
$\mathrm{C}_{17: 1} \omega 7 \mathrm{c}$ & 11.9 & 16.2 & 2.8 \\
$\mathrm{C}_{18: 1} \omega 7 \mathrm{c}$ & 7.0 & - & 1.3 \\
Branched fatty acids & 2.6 & 7.9 & 1.9 \\
anteiso- $\mathrm{C}_{15: 0}$ & 11.7 & - & 5.6 \\
anteiso-C & & - & 11.1 \\
iso- $\mathrm{C}_{14: 0}$ & 8.9 & - & - \\
iso- $\mathrm{C}_{16: 0}$ & 3.1 & 1.1 & 12.7 \\
\hline
\end{tabular}

Therefore, it is evident from the genotypic and phenotypic data that strain jys $28^{\mathrm{T}}$ represents a novel species of the genus Streptomyces, for which the name Streptomyces piniterrae sp. nov. is proposed.

\subsection{Description of Streptomyces piniterrae sp. nov.}

Streptomyces piniterrae (pi.ni.ter'ra.e. L. n. pinus name of a plant and also a botanical generic name (Pinus); L. n. terra soil; N.L. gen. n. piniterrae of soil of pinus, denoting the source of the type strain).

Gram-stain-positive and aerobic actinomycete that forms well-developed, branched substrate hyphae and aerial mycelium that differentiate into spiral spore chains with oval spores. The spore surface is spiny. The colour of aerial mass varies from pure white to dark gray. Diffusible pigments are observed on ISP 2, ISP3, ISP5, ISP6, ISP7, NA and CA. Growth is observed at temperatures between 15 and $40^{\circ} \mathrm{C}$, with an optimum temperature of $28^{\circ} \mathrm{C}$. Growth occurs at $\mathrm{pH}$ values between 4 and 8 (optimum $\mathrm{pH} 7$ ) and $11 \% \mathrm{NaCl}$ tolerance. It is positive for production of urease, negative for hydrolysis of starch, aesculin, Tweens (20, 40 and 80), production of $\mathrm{H}_{2} \mathrm{~S}$, peptonization and coagulation of milk, decomposition of cellulose, liquefaction of gelatin and reduction of nitrate. Dulcitol, D-fructose, D-galactose, D-glucose, meso-inositol, lactose, D-maltose, D-mannitol, D-mannose, D-raffinose, L-rhamnose, D-ribose, D-sorbitol and D-sucrose are utilized as sole carbon sources but not L-arabinose and D-xylose. L-Alanine, L-arginine, L-asparagine, L-aspartic acid, glycine, L-glutamic acid, L-glutamine, L-proline and L-tyrosine are utilized as sole nitrogen sources but not creatine, L-serine, L-threonine and L-tryptophan. The cell wall diamino acid is LL-diaminopimelic acid. Whole-cell sugars contain glucose and xylose. The menaquinones are MK-9( $\left.\mathrm{H}_{6}\right), \mathrm{MK}-9\left(\mathrm{H}_{8}\right)$ and $\mathrm{MK}-9\left(\mathrm{H}_{4}\right)$. The phospholipid profile consists of diphosphatidylglycerol, phosphatidylmethylethanolamine, phosphatidylethanolamine and phosphatidylinositol mannoside. The major fatty acids $(>10 \%)$ are iso- $\mathrm{C}_{16: 0}, \mathrm{C}_{15: 0}, \mathrm{C}_{16: 1} \omega 7$ cand anteiso- $\mathrm{C}_{15: 0}$.

The type strain, jys $28^{\mathrm{T}}\left(=\mathrm{CCTCC}\right.$ AA $\left.2018051^{\mathrm{T}}=\mathrm{DSM} 109823^{\mathrm{T}}\right)$, was isolated from rhizosphere soil of P. yunnanensis collected from Yuxi, Yunnan Province, southwest China. The DNA G+C content of the draft genome sequence of the type strain indicates a value of approximately $70.6 \mathrm{~mol} \%$ for 
the species. The GenBank accession number for the 16S rRNA gene sequence and the draft genome sequence of the type strain are MH620762 and SUMB00000000, respectively.

\subsection{Identification of Secondary Metabolic Biosynthetic Gene Clusters, Including the Putative BGC for Heliquinomycins}

Sequencing of the genome produced an annotated genome size of approximately $8.5 \mathrm{Mbp}(28$ scaffolds). This draft genome sequence has been deposited at the GenBank/EMBL/DDBJ under the accession number SUMB00000000. The genome contains one linear chromosome with 7 rRNA operons, 67 tRNA genes and 7543 protein-coding genes (CDSs). Genome sequencing showed the DNA G + C content of strain jys $28^{\mathrm{T}}$ to be $70.6 \mathrm{~mol} \%$. AntiSMASH analysis led to the identification of 33 putative gene clusters in the genome of strain $\mathrm{jys} 28^{\mathrm{T}}$. Five of these clusters were identified belonging to the family of polyketide synthases (PKSs), including type I (three clusters), II (one clusters) and III (one cluster). Likewise, genome sequence analysis detected seven additional gene clusters comprising modular enzyme coding genes such as non-ribosomal peptide synthetase (NRPS, five clusters) and hybrid PKS I-NRPS genes (three clusters). Other gene clusters included terpene (seven clusters), butyrolactone (two clusters), siderophore (four clusters), lantipeptide (two clusters), bacteriocin (two clusters), ladderane (two clusters) and ectoine (one cluster).

Based on BLAST sequence analysis, we deduced the biosynthetic gene cluster of heliquinomycins, which contained 10 polyketide core genes (4027-4030, 4033 and 4046-4050), 21 tailoring genes (4036, 4038-4042, 4051, 4054-5058 and 4060-4068), 2 regulatory genes (4024 and 4025), 1 resistance gene (4059) and 11 unassigned or unknown functional genes $(4026,4031,4032,4034,4035,4037,4043-4045,4052$ and 4053) (Table S3). The gene cluster displayed high homology with that of griseorhodin A identified in Streptomyces sp. JP95 (Figure 4A) [45].

So far as is known, griseorhodin A was derived from iterative PKS pathway. Then, post-PKS modifications produce the intriguing 5, 6-spiroketal core through a highly complex oxidative tailoring process [46]. In line with griseorhodin A biosynthetic pathway, the carbon chain of heliquinomycin and 9'-methoxy-heliquinomycin was also elongated by mimic PKS and modified by putative 3-oxoacyl-ACP reductase (4051 and/or 4056) (Figure 4B) [13]. One of the difference between griseorhodin A and heliquinomycins is the methoxycarbonyl group at position C-25. Results of the comparison between grh and $h l q$ showed an extra cytochrome P450 (4054) and an extra SAM-dependent methyltransferase (4055) in hlq gene cluster. The protein sequence of 4045 hits the conserved domain of ent-kaurene oxidase that suggests a function for 4045 in the three successive oxidations of C-26 [47]. Moreover, $r u b U$, a homologous gene of 4054 , has been found in rubromycin $(r u b)$ biosynthetic gene cluster, which could characterize the role of 4054 from the side as rubromycin does have the same methoxycarbonyl group at position C-25. After the three-step-oxidation of C-26, a methyl group was introduced to the carboxyl group by putative methyltransferase 4040. Besides the methylation of this position, methyltransferase 4040 might also play a role at hydroxy group of A ring. The extra SAM-dependent methyltransferase (4055) was speculated to be responsible for the methoxy group of B ring as a result of the absent of this gene in both grh and rub clusters. Refer to the implied intermediates of rubromycins, methoxycarbonyl-collinone and methoxycarbonyl-lenticulone would probably be intermediates of heliquinomycins, which was tentatively verified by gene knockout experiment with the corresponding enzymes to FAD-dependent monooxygenase (4039) and GNAT family $N$-acetyltransferase (4037) [15,48]. The hydroxyl group on D ring showed another difference in structure between griseorhodin A and heliquinomycins. A relevant putative cytochrome P450 was present in both grh (grhO3) and $h l q$ (4057) clusters, which might relate to the hydroxyl group or the epoxide in D ring of heliquinomycin and griseorhodin A, respectively. The proposed biosynthetic pathway for 2,6-dideoxy-3-O-methylhexopyranose sugar moiety of heliquinomycins was shown in Figure $4 \mathrm{C}$. The gene cluster of the pyranose in $h l q$ is $75 \%$ similar to that of ave [49,50]. Under the action of putative glycosytransferase (4066), ultimately formed the heliquinomycins. In conclusion, the relatively definite gene clusters of these spiroketal compounds have already been found previously, but 
the individual mechanism and substrate specificities of those numerous interesting tailoring enzymes have not been identified yet. Therefore, additional studies need to be carried out.

A
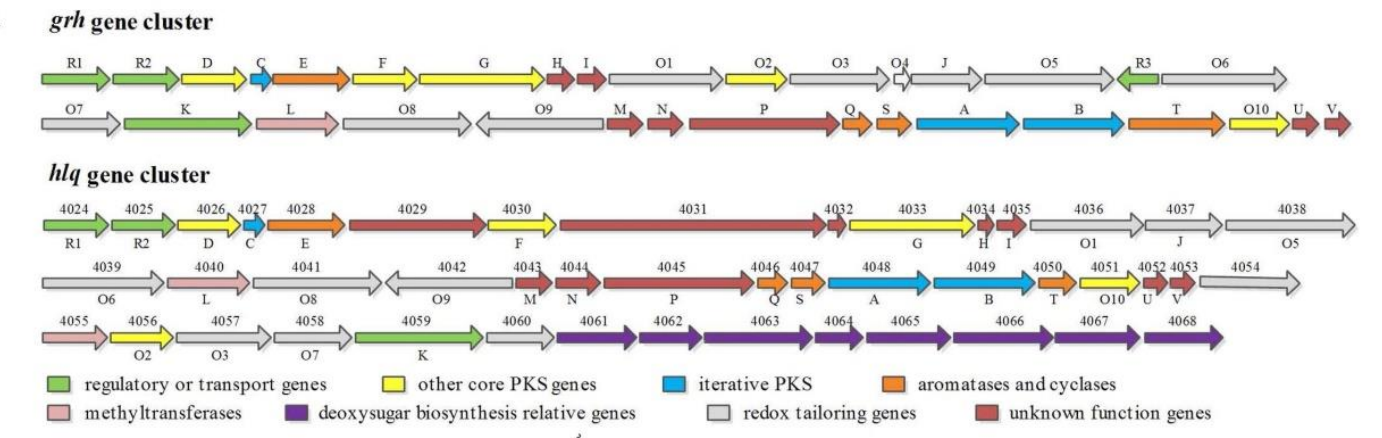

B
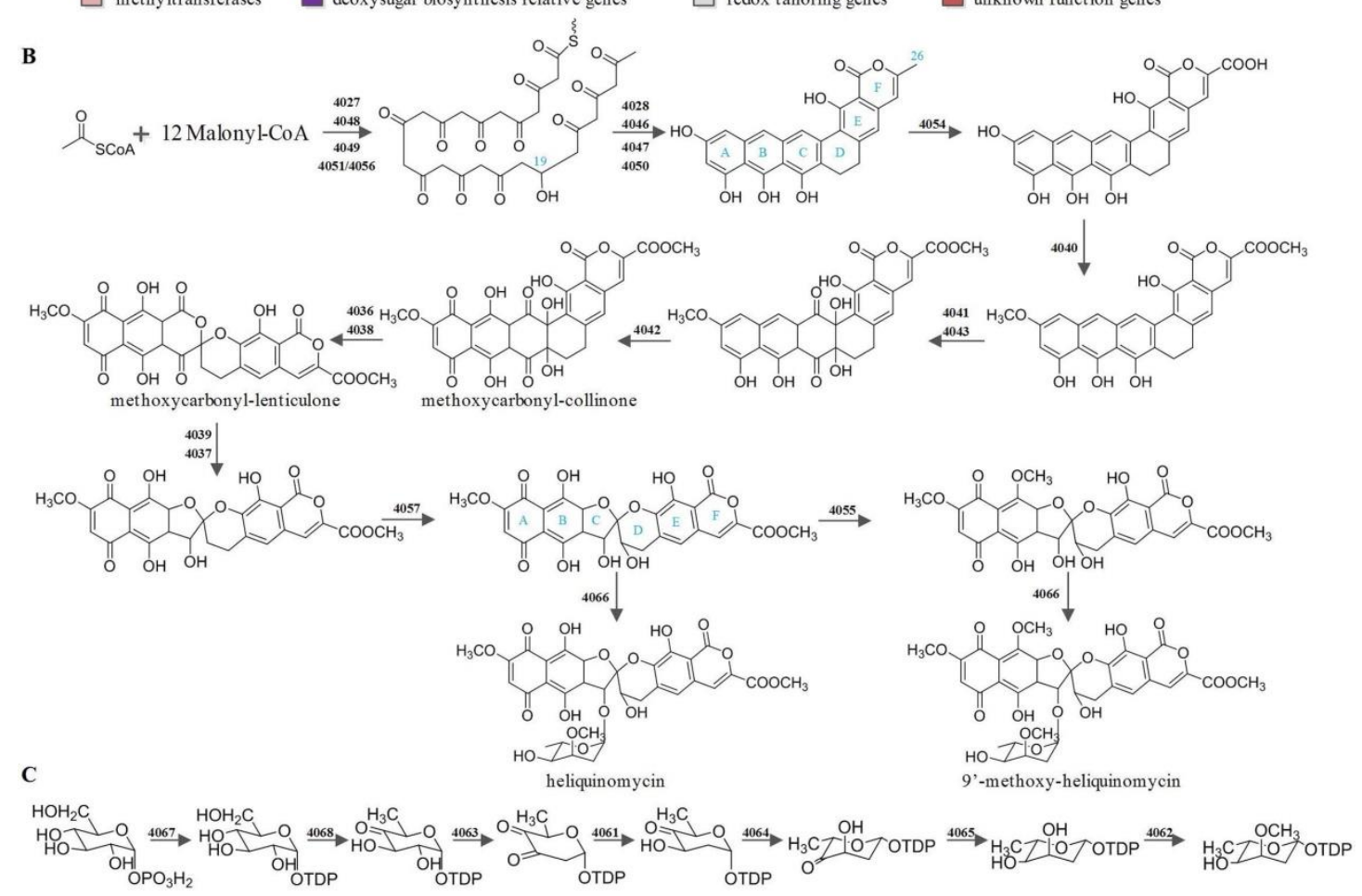

Figure 4. Identification of biosynthetic information of heliquinomycins. (A). Biosynthetic gene clusters of griseorhodin A $(g r h)$ and heliquinomycins $(h l q)$. Individual genes are labeled by their numbers or names above the arrows. Genes of grh gene cluster which are homologous to those of $h l q$ are exhibited under the arrows. (B). Proposed biosynthesis of the heliquinomycins. (C). Proposed biosynthesis of the 2,6-dideoxy-3-O-methylhexopyranose sugar moiety of heliquinomycins.

\section{Conclusions}

A heliquinomycin-producing strain, jys $28^{\mathrm{T}}$, was isolated from the rhizosphere soil of Pinus yunnanensis. Morphological and chemotaxonomic features together with phylogenetic analysis suggested that strain jys $28^{\mathrm{T}}$ belonged to the genus Streptomyces. Physiological and biochemical characteristics combined with ANI and dDDH values clearly revealed that strain jys $28^{\mathrm{T}}$ was differentiated from its closely related strains. Based on the polyphasic taxonomic analysis, it is suggested that strain jys $28^{\mathrm{T}}$ represents a novel species of the genus Streptomyces, for which the name Streptomyces piniterrae sp. nov. is proposed. The type strain is jys $28^{\mathrm{T}}\left(=\right.$ CCTCC AA $2018051^{\mathrm{T}}=\mathrm{DSM}$ $109823^{\mathrm{T}}$ ). In addition, the biosynthetic pathway and gene cluster of heliquinomycins were deduced by whole-genome analysis.

Supplementary Materials: The following are available online at http://www.mdpi.com/2076-2607/8/4/495/s1. 
Author Contributions: X.Z., C.P., C.S. and C.G. performed the experiments. C.L., Z.W. and Y.W. analyzed the data. C.L. and Z.W. wrote the paper. C.L. designed the experiments. S.H. reviewed the manuscript. All authors read and approved the final manuscript.

Funding: This work was supported by the Academic Backbone Project of Northeast Agricultural University (Grant No. 17XG17) and Postdoctoral Start-up Fund of Heilongjiang Province (LBH-Q19011).

Acknowledgments: We thanks Aharon Oren for his valuable help with naming the species.

Conflicts of Interest: The authors declare no conflicts of interest.

\section{References}

1. Bérdy, J. Bioactive microbial metabolites. J. Antibiot. 2005, 58, 1-26. [CrossRef] [PubMed]

2. Procópio, R.E.; Silva, I.R.; Martins, M.K.; Azevedo, J.L.; Araújo, J.M. Antibiotics produced by Streptomyces. Braz. J. Infect. Dis. 2012, 16, 466-471. [CrossRef] [PubMed]

3. Su, C.; Liu, C.X.; Wang, Y.J.; Xiang, W.S.; Zou, C.G.; Huang, S.X. A new heliquinomycin analogue with immunosuppressive activity from Streptomyces sp. jys28. Rec. Nat. Prod. 2019, 13, 456-461. [CrossRef]

4. Brockmann, H.; Renneberg, K.H. Rubromycin, ein rotes antibiotikum aus actinomyceten. Sci. Nat.-Heidelberg. 1953, 40, 59-60. [CrossRef]

5. Waters, S.P.; Fennie, M.W.; Kozlowski, M.C. Convergent route to the purpuromycin bisphenolic spiroketal: Hydrogen bonding control of spiroketalization stereochemistry. Tetrahedron. Lett. 2006, 47, 5409-5413. [CrossRef]

6. Eckardt, K.; Tresselt, D.; Ihn, W. The structure of the antibiotic griseorhodin C. J. Antibiot. 1978, 31, 970-973. [CrossRef]

7. Chino, M.; Nishikawa, K.; Umekita, M.; Hayashi, C.; Yamazaki, T.; Tsuchida, T.; Sawa, T.; Hamada, M.; Takeuchi, T. Heliquinomycin, a new inhibitor of DNA helicase, produced by Streptomyces sp. MJ929-SF2. I. taxonomy, production, isolation, physico-chemical properties and biological activities. J. Antibiot. 1996, 49, 752-757. [CrossRef]

8. Yuen, T.Y.; Ng, Y.P.; Ip, F.C.F.; Chen, J.L.Y.; Atkinson, D.J.; Sperry, J.; Ip, N.Y.; Brimble, M.A. Telomerase inhibition studies of novel spiroketal containing rubromycin derivatives. Aust. J. Chem. 2013, 66, 530-533. [CrossRef]

9. Takamasa, U.; Hirotada, T.; Masako, O.; Mizunuma, M.; Yokoyama, A.; Goto, Y.; Mizushina, Y.; Sakaguchi, K.; Hayashi, H. Inhibition of human telomerase by rubromycins:? Implication of spiroketal system of the compounds as an active moiety. Biochemistry 2000, 39, 5995-6002.

10. Mizushinaa, Y.; Ueno, T.; Oda, M.; Yamaguchi, T.; Saneyoshi, M.; Sakaguchi, K. The biochemical mode of inhibition of DNA polymerase $\beta$ by $\alpha$-rubromycin. BBA-Gen. Subjects. 2000, 1523, 172-181. [CrossRef]

11. Wu, K.L.; Mercado, E.V.; Pettus, T.R. A convergent total synthesis of $( \pm)-\gamma$-rubromycin. J. Am. Chem. Soc. 2011, 133, 6114-6117. [CrossRef] [PubMed]

12. Wei, L.P.; Xue, J.J.; Liu, H.B.; Wang, W.J.; Li, Y. Synthesis of $( \pm)-\gamma$-rubromycin via a new hypoiodite-catalytic oxidative cycloetherification. Org. Lett. 2012, 20, 5302-5305. [CrossRef] [PubMed]

13. Xu, Z.L.; Schenk, A.; Hertweck, C. Molecular analysis of the benastatin biosynthetic pathway and genetic engineering of altered fatty acid-polyketide hybrids. J. Am. Chem. Soc. 2007, 129, 6022-6030. [CrossRef] [PubMed]

14. Lackner, G.; Schenk, A.; Xu, Z.L.; Reinhardt, K.; Yunt, Z.S.; Piel, J.; Hertweck, C. Biosynthesis of pentangular polyphenols: Deductions from the benastatin and griseorhodin pathways. J. Am. Chem. Soc. 2007, 129, 9306-9312. [CrossRef]

15. Yunt, Z.; Reinhardt, K.; Li, A.Y.; Engeser, M.; Dahse, H.M.; Gutschow, M.; Bruhn, T.; Bringmann, G.; Piel, J. Cleavage of four carbon-carbon bonds during biosynthesis of the griseorhodin A spiroketal pharmacophore. J. Am. Chem. Soc. 2009, 131, 2297-2305. [CrossRef]

16. Liu, C.X.; Zhuang, X.X.; Yu, Z.Y.; Wang, Z.Y.; Wang, Y.J.; Guo, X.W.; Xiang, W.S.; Huang, S.X. Community structures and antifungal activity of root-associated endophytic actinobacteria of healthy and diseased soybean. Microorganisms 2019, 7, 243. [CrossRef]

17. Shirling, E.B.; Gottlieb, D. Methods for characterization of Streptomyces species. Int. J. Syst. Bacteriol. 1966, 16, 313-340. [CrossRef] 
18. Waksman, S.A. The Actinomycetes. In A Summary of Current Knowledge; Ronald Press: New York, NY, USA, 1967.

19. Jones, K.L. Fresh isolates of actinomycetes in which the presence of sporogenous aerial mycelia is a fluctuating characteristic. J. Bacteriol. 1949, 57, 141-145. [CrossRef]

20. Zhao, J.W.; Han, L.Y.; Yu, M.Y.; Cao, P.; Li, D.M.; Guo, X.W.; Liu, Y.Q.; Wang, X.J.; Xiang, W.S. Characterization of Streptomyces sporangiiformans sp. nov., a novel soil actinomycete with antibacterial activity against Ralstonia solanacearum. Microorganisms 2019, 7,360. [CrossRef]

21. Gordon, R.E.; Barnett, D.A.; Handerhan, J.E.; Pang, C. Nocardia coeliaca, Nocardia autotrophica, and the nocardin strain. Int. J. Syst. Bacteriol. 1974, 24, 54-63. [CrossRef]

22. Yu, Z.Y.; Han, C.Y.; Yu, B.; Zhao, J.W.; Yan, Y.J.; Huang, S.X.; Liu, C.X.; Xiang, W.S. Taxonomic characterization, and secondary metabolite analysis of Streptomyces triticiradicis sp. nov.: A novel actinomycete with antifungal activity. Microorganisms 2020, 8, 77. [CrossRef] [PubMed]

23. McKerrow, J.; Vagg, S.; McKinney, T.; Seviour, E.M.; Maszenan, A.M.; Brooks, P.; Sevious, R.J. A simple HPLC method for analyzing diaminopimelic acid diastereomers in cell walls of Gram-positive bacteria. Lett. Appl. Microbiol. 2000, 30, 178-182. [CrossRef] [PubMed]

24. Lechevalier, M.P.; Lechevalier, H.A. The Chemotaxonomy of Actinomycetes. In Actinomycete Taxonomy; Dietz, A., Thayer, D.W., Eds.; Special Publication for Society of Industrial Microbiology: Arlington, TX, USA, 1980; pp. 227-291.

25. Minnikin, D.E.; O’Donnell, A.G.; Goodfellow, M.; Alderson, G.; Athalye, M.; Schaal, A.; Parlett, J.H. An integrated procedure for the extraction of bacterial isoprenoid quinones and polar lipids. J. Microbiol. Methods. 1984, 2, 233-241. [CrossRef]

26. Collins, M.D. Isoprenoid Quinone Analyses in Bacterial Classification and Identification. In Chemical Methods in Bacterial Systematics; Goodfellow, M., Minnikin, D.E., Eds.; Academic Press: Cambridge, MA, USA, 1985; pp. 267-284.

27. Zhuang, X.X.; Peng, C.H.; Wang, Z.Y.; Zhao, J.W.; Shen, Y.; Liu, C.X.; Xiang, W.S. Actinomadura physcomitrii sp. nov., a novel actinomycete isolated from moss [Physcomitrium sphaericum (Ludw) Fuernr]. Antonie. Leeuwenhoek. 2020. [CrossRef]

28. Wang, Z.Y.; Yu, Z.Y.; Zhao, J.W.; Zhuang, X.X.; Cao, P.; Guo, X.W.; Liu, C.X.; Xiang, W.S. Community composition, antifungal activity and chemical analyses of ant-derived actinobacteria. Front. Microbiol. 2020, 11, 201. [CrossRef]

29. Yoon, S.H.; Ha, S.M.; Kwon, S.; Lim, J.; Kim, Y.; Seo, H.; Chun, J. Introducing EzBioCloud: A taxonomically united database of 16S rRNA and whole genome assemblies. Int. J. Syst. Evol. Microbiol. 2017, 67, 1613-1617. [CrossRef]

30. Saitou, N.; Nei, M. The neighbor-joining method: A new method for reconstructing phylogenetic trees. Mol. Biol. Evol. 1987, 4, 406-425.

31. Felsenstein, J. Evolutionary trees from DNA sequences: A maximum likelihood approach. J. Mol. Evol. 1981, 17, 368-376. [CrossRef]

32. Kimura, M. A simple method for estimating evolutionary rates of base substitutions through comparative studies of nucleotide sequences. J. Mol. Evol. 1980, 16, 111-120. [CrossRef]

33. Kumar, S.; Stecher, G.; Tamura, K. Mega7: Molecular evolutionary genetics analysis version 7.0 for bigger datasets. Mol. Biol. Evol. 2016, 33, 1870-1874. [CrossRef]

34. Nikodinovic, J.; Barrow, K.D.; Chuck, J.A. High yield preparation of genomic DNA from Streptomyces. Biotechniques 2003, 35, 932-934. [CrossRef] [PubMed]

35. Coil, D.; Jospin, G.; Darling, A.E. A5-miseq: An updated pipeline to assemble microbial genomes from Illumina MiSeq data. Bioinformatics 2015, 31, 587-589. [CrossRef] [PubMed]

36. Blin, K.; Wolf, T.; Chevrette, M.G.; Lu, X.; Schwalen, C.J.; Kautsar, S.A.; Duran, H.G.S.; Santos, E.L.C.D.L.; Kim, H.U.; Nave, M.; et al. Antismash 4.0-improvements in chemistry prediction and gene cluster boundary identification. Nucleic. Acids. Res. 2017, 45, W36-W41. [CrossRef] [PubMed]

37. Meier-Kolthoff, J.P.; Auch, A.F.; Klenk, H.P.; Goker, M. Genome sequence-based species delimitation with confidence intervals and improved distance functions. BMC. Bioinform. 2013, 14, 60. [CrossRef] [PubMed]

38. Yoon, S.H.; Ha, S.M.; Lim, J.; Kwon, S.; Chun, J. A large scale evaluation of algorithms to calculate average nucleotide identity. Antonie. Leeuwenhoek. 2017, 110, 1281-1286. [CrossRef] 
39. Wayne, L.G.; Brenner, D.J.; Colwell, R.R.; Grimont, P.A.D.; Kandler, O. Report of the ad hoc committee on reconciliation of approaches to bacterial systematics. Int. J. Syst. Bacteriol. 1987, 37, 463-464. [CrossRef]

40. Richter, M.; Rosselló-Móra, R. Shifting the genomic gold standard for the prokaryotic species definition. Proc. Natl. Acad. Sci. USA 2009, 106, 19126-19131. [CrossRef]

41. Rong, X.; Huang, Y. Taxonomic evaluation of the Streptomyces hygroscopicus clade using multilocus sequence analysis and DNA-DNA hybridization, validating the MLSA scheme for systematics of the whole genus. Syst. Appl. Microbiol. 2012, 35, 7-18. [CrossRef]

42. Kämpfer, P.; Genus, I. Streptomyces Waksman and Henrici 1943, 339 AL. In Bergey's Manual of Systematic Bacteriology, 2nd ed.; Springer: New York, NY, USA, 2012; pp. 1679-1680.

43. Kim, B.Y.; Zucchi, T.D.; Fiedler, H.P.; Goodfellow, M. Streptomyces staurosporininus sp. nov., a staurosporine-producing actinomycete. Int. J. Syst. Evol. Microbiol. 2012, 62, 966-970. [CrossRef]

44. Lechevalier, M.P.; Lechevalier, H.A. Chemical composition as a criterion in the classification of aerobic actinomycetes. Int. J. Syst. Bacteriol. 1970, 20, 435-443. [CrossRef]

45. Li, A.; Piel, J. A gene cluster from a marine Streptomyces encoding the biosynthesis of the aromatic spiroketal polyketide griseorhodin A. Chem. Biol. 2002, 9, 1017-1026. [CrossRef]

46. Puder, C.; Loya, S.; Hizi, A.; Zeeck, A. Structural and biosynthetic investigations of the rubromycins. Eur. J. Org. Chem. 2000, 5, 729-735. [CrossRef]

47. Helliwell, C.A.; Chandler, P.M.; Poole, A.; Dennis, E.S.; Peacock, W.J. The CYP88A cytochrome P450, ent-kaurenoic acid oxidase, catalyzes three steps of the gibberellin biosynthesis pathway. Proc. Natl. Acad. Sci. USA 2001, 98, 2065-2070. [CrossRef] [PubMed]

48. Martin, R.; Sterner, O.; Alvarez, M.A.; Clercq, E.D.; Bailey, J.E.; Minas, W.G. Collinone, a new recombinant angular polyketide an engineered Streptomyces strain. J. Antibiot. 2001, 54, 239-249. [CrossRef] [PubMed]

49. Ikeda, H.; Nonomiya, T.; Usami, M.; Ohta, T.; Omura, S. Organization of the biosynthetic gene cluster for the polyketide anthelmintic macrolide avermectin in Streptomyces avermitilis. Proc. Natl. Acad. Sci. USA 1999, 96, 9509-9514. [CrossRef]

50. Wohlert, S.E.; Lomovskaya, N.; Kulowski, K.; Fonstein, L.; Occi, J.L.; Gewain, K.M.; MacNeil, D.J.; Hutchinson, C.R. Insights about the biosynthesis of the avermectin deoxysugar L-oleandrose through heterologous expression of Streptomyces avermitilis deoxysugar genes in Streptomyces lividans. Chem. Biol. 2001, 8, 681-700. [CrossRef] 